\title{
ASSESSMENT OF LEGALITY OF ANTI-TERRORIST SCREENING OF JOB SEEKERS UNDER EU LAW AND NATIONAL LAW. A Theoretical and Practical Approach
}

\author{
Jana Žul’ová ${ }^{1}$, Marek Švec ${ }^{2}$
}

\begin{abstract}
The aim of the scientific paper is to identify employer's options when engaging in antiterrorist screening of future employees and to assess the compliance of such a procedure with the relevant European and national legislation. Through the use of qualitative scientific methods such as the analytical-descriptive method, comparison, critical analysis, induction, deduction, and synthesis of the acquired knowledge, the authors draw attention to a different approach to choosing appropriate legal bases for processing relevant information about employees, including different approach to labour law and the personal data protection law. The analysis of the principle of legality of personal data processing in the framework of anti-terrorist screening of job seekers takes into account a specific position of the job seeker as a weaker party to the prospective employment agreement.
\end{abstract}

\section{Keywords}

Anti-terrorist Screening, Terrorists List, Job Seeker, GDPR, Integrity

\section{Introduction}

The world has changed since September 11, 2001. The illusion of inviolable security of the world superpower and its allies has collapsed, and it has become clear that terrorism is capable of posing a continuous global threat (Zaušková et al., 2014). From this moment onward, security and its assurance in various areas of social and working life has become not only the social) responsibility but also a necessity. For almost twenty years now, states have been taking various precautionary measures to protect against an enemy who is fighting in an unpredictable way, failing to respect international law and ignoring fundamental human values. The European Union Report on the Situation and Trends in Terrorism (TE-SAT) 2020, published on 23 June 2020, states that the terrorist threat remains high in the European Union. The data collected for 2019 show that:

\footnotetext{
${ }^{1}$ University in Košice, Kováčska 26, Košice, 04075 Košice, Slovakia. E-mail: jana.zulova@upjs.sk.

${ }^{2}$ Matej Bel University in Banská Bystrica, Komenského 3730/20, 97401 Banská Bystrica, Slovakia.

E-mail: msvec@umb.sk.
} 
* A total of 119 foiled, failed and completed terrorist attacks were reported by a total of 13 EU Member States;

* 1004 individuals were arrested on suspicion of terrorism-related offenses in $19 \mathrm{EU}$ Member States, with Belgium, France, Italy, Spain and the UK reporting the highest numbers;

* Ten people died because of terrorist attacks in the EU and 27 people were injured.

The state, or a transnational grouping such as the European Union, has mechanisms in place to adopt various restrictive measures to combat terrorism, which are then reflected in areas that are not primarily related to the fight against terror. The measures are taken from the position of public authorities and within the framework of state coercion, they may be enforced through sanctions for non-compliance. In order to protect the public interest, the security measures regularly aim to restrict freedom and interfere with fundamental human rights and freedoms. However, subordination of human rights to the interests of security is perceived with great sensitivity (Zaušková et al., 2013). In many cases, the blame falls on failure to protect the borders and opinions are voiced that sacrificing human rights to fight terrorism does not correspond to the real struggle with this threat to freedom and security, but that it has rather became a tool for fulfilling egocentric (mostly political) interests of states (Kupsa, 2008). It is then necessary to consider very carefully what role or position the private sector can have in this fight, how it can be helpful in this respect and whether in some cases it is no longer only extra work with the aim of pursuing other (own) goals. In accordance with the professional and scientific profile of the authors of the present paper, their scientific article focuses on the employer operating in the private sector. In application practice, in the last few years (especially after the adoption of the Regulation of the European Parliament and of the Council of the European Union no. 2016/679 on the protection of individuals with regard to the processing of personal data and on the free movement of such data, repealing Directive no. 95/46/EC, hereinafter referred to as GDPR), we have come across a question of whether the employer may check whether job seekers interested in working for it have been involved in a terrorist act or have sympathized in any way with demonstration of such violence in their private life or did so in their previous professional career. The issue in question is becoming so serious that it may be the cause of the employer's restricted pursuit of its business activity. Conducting anti-terrorist screening is often one of the basic conditions for an employer to be able to apply for commercial contracts with businesses incorporated in the United States of America or Israel. Quite often, however, we also encounter a situation where the requirement is included in the so-called due diligence or the rules of conduct of suppliers of a particular company, in addition to the obligation to implement rules related to anticorruption measures and anti-bribery measures, including setting appropriate procedures to prevent the receipt of commissions and defining the principles of gifts or benefits, and the applicant for a commercial contract must declare that its internal processes and procedures are compliant with those requirements (Nováčková, 2020). In an effort to satisfy such business partner, employers try to implement anti-terrorism screening in their internal processes, but often without a deeper examination of the impact on the rights of the persons 
concerned and without its deeper integration into the employer's internal environment. For example, in the conditions of the Slovak Republic, these could conflict with the competencies of employee representatives in implementation of the control mechanism or with the employer's ability to process such information about a potential employee at all. Assessing the compatibility of anti-terrorist screening with legislation in the area of personal data protection and labour law requires a systematic legal analysis of the scope of information the employer may collect and further process about the candidate in the process of filling the vacancy. The job seeker's right to their privacy, including the right to protection of their personal data, is jeopardized and the legitimate question arises of the existence of the employer's right to process this type of information at all. The aim of this scientific contribution is to assess, using several scientific methods, the legality of the employer's conduct when the employer seeks to find out whether the job seeker is on the terrorists list, sympathizes in any way with such forms and expressions of violence or ideas of this movement, or directly or indirectly participates in the same (hereinafter referred to as the so-called anti-terrorist screening), in the legal framework of Union law and national (Slovak) law.

\section{Anti-terrorist Screening as Part of the Pre-employment Background Check}

Anti-terrorist screening is usually part of the so-called pre-employment background check. Increased demand for anti-terrorist screening of jobseekers is described as one of the main consequences of the 9/11 attacks on HRM (Kondrasuk, 2004). This is an additional method used at the end of the implementation phase of filling the employer's vacancy. Personnel specialists use this method to verify the accuracy, completeness, and truthfulness of information that the natural person applying for employment has so far provided or has failed to provide, where this information is important to the employer in terms of the work to be performed. According to various available internet surveys, many respondents admit that they are deliberately misleading in their résumés, either by embellishing and enhancing their abilities and skills compared to an objective state of reality, or by purposefully withholding some information so as not to be disqualified from the selection process. In principle, the pre-employment background check is not generally prohibited by law. And as long as certain limits are respected, there is no reason to prohibit such action by the employer. However, the assessment of whether the limits have been transgressed is indeed an important and essential legal issue, especially in cases where these limits result from Union law, but also from national law. The basic legal framework of the Union that must be respected in this process is the anti-discrimination directives and the GDPR. Further limits may be set by national law in the field of individual employment relationships or collective employment relationships and the protection of personal data.

\section{Anti-terrorist screening in the context of anti-discrimination legislation}

Just as a natural person has the right to choose an employer, so does the one who wants to employ someone has the right to choose an employee. However, the construct of free choice of a contractual partner created by the theory of labour law as an immanent content part of the principle of contractual freedom has its limits (Dolobáč, 2017). The employer fills the 
vacancies according to its operational and economic possibilities, it chooses the conditions and the method. Selection of employees and their subsequent check is thus available to the employer, but subject to the principle of equal treatment and non-discrimination. The employer may not base its decisions on any of the protected characteristics and, therefore, such characteristic may not be subject to review or assessment. In European antidiscrimination law, we are talking specifically about the following protected characteristics: gender, sexual orientation, disability, age, race, ethnic origin, nationality and religion or belief. An exception applies where it is justified by the nature of the activities pursued in employment or the circumstances in which those activities are pursued, where that reason constitutes a genuine and critical requirement for employment, provided that the objective is legitimate, and the requirement is proportionate.

Therefore, if the employer checks the information whether the job seeker is in any way connected to terrorist activities or sympathizes with them to such an extent that his actions or expressions are capable of endangering the interests of the employer, anti-discrimination legislation must be taken into account in the first step. It would be contrary to this legislation for an employer to act if only persons of a certain race or members of a minority were subject to check. For example, focus on radicalization has led to stigmatization of the Muslim community, but also of refugees and migrants in general (Tucker, 2016). Doubling down on employer's preventive measures in the form of anti-terrorist screening aimed only at certain job seekers, deliberately selected from these groups, is based on prejudice and is not legally consistent with general anti-discrimination legislation.

\section{Anti-terrorist screening in the context of GDPR}

Protection of personal data begins with the process of collecting information about job seekers and their documents. Those include, e.g., a job application, a résumé, a personal questionnaire, a cover letter, a proof of education (school reports, diplomas, certificates) and internships. The HR specialist assesses the completeness and formal aspect of the documents and determines the relevance of the information. Basic profile of the candidate is created, and the candidate is shortlisted for selection. It is up to the HR specialist to consider the information provided as credible or to check its veracity, or even to actively seek other information not provided by the applicants, such as information on terrorismrelated manifestations and activities.

Anti-terrorist screening most often consists of checking whether the jobseeker's name is on the list of globally maintained terrorists databases or also going through the job seeker's digital footprint, especially the one he leaves on social networks (see the third part of the paper below). Pursuant to Art. 4 point 1 of the GDPR, personal data is deemed to be: "any information relating to an identified or identifiable natural person ('data subject'); an identifiable natural person is one who can be identified, directly or indirectly, in particular by reference to an identifier such as a name, an identification number, location data, online identifier or by reference to one or more factors specific to the physical, physiological, genetic, mental, economic, cultural or social identity of that natural person." This is an exemplary enumeration of data that can be considered personal. In order for such data to be considered personal, they must relate to an already identified person or a person directly 
or indirectly identifiable by the data. A person is identifiable when additional information, making it possible for the person to be identified, can be obtained without undue effort. In addition to identifying an individual, the data must relate to the individual, i.e., the data may (must) affect a particular natural person (e.g., it may be of the nature to cause them harm). In terms of content, personal data is any kind of information about a person concerning their private, family, work and public life. The carrier (format) of personal data is not decisive for the application of the rules of data protection (paper, electronic, graphic, numerical, photographic, video-audio, audio form). The information does not have to be true or proven in order to be marked as personal data. The assessment of whether the data obtained is personal must always be made within the specific context of the processing. In view of the above, it is indisputable that the anti-terrorist screening itself, as well as other processes constituting a part thereof, are processes in which personal data are processed. In accordance with Art. 4 point 2 of the GDPR, the search for information on candidates, collection, organization ... verification of this information is a processing operation that concerns personal data, and is, therefore, subject to the legal regime of the GDPR. In order for an employer (i.e., the controller, according to the GDPR terminology) to be able to lawfully process personal data of job seekers (i.e., the data subjects, according to the GDPR terminology), it must establish a legitimate purpose for personal data processing and treat the processing operations according to an appropriately chosen legal basis.

The aim of anti-terrorist screening of jobseekers is to prevent terrorism and maintain security by employing only an individual who has not been identified as participating in any terrorist-related activities or who cannot be expected to act or express himself in this regard at all. The aim is, therefore, to prevent such persons from accessing strategic occupations such as working at airports, in public services (energy, information and communication systems, armaments industry, transport), etc. Persons who have been identified as being involved in terrorism or other serious crimes related thereto, as well as persons who could, in theory, later, using the means of employers, assist in these activities, or disseminate information about them. The purpose of screening is, on the one hand, prevention and security of public order, but also protection of fundamental human rights and freedoms. Secondarily, however, anti-terrorist screening is also used to assess possible harm to the employer's interests, especially from employees in managerial positions and positions that come into contact with the employer's business partners, and any action by such an employee could theoretically not only damage the employer's repute, but also interfere with its internal or external communication, chances of winning new business contracts, etc. (Hitka et al., 2019). The goal or purpose thus determined can be considered legitimate, but attention must be paid to the lawfulness of the means and manners by which it is achieved. Proportionality to the resulting consequences must also be considered. The right to personal data protection and the right to free access to employment are at stake (Zoričáková, 2020).

As we have said, each processing operation should be dealt with from an appropriately chosen legal basis. Art. 6 of the GDPR provides in simplified terms the following six legal bases: (i) consent of the data subject, (ii) processing is necessary for contract performance or for implementation of pre-contractual measures; (iii) compliance with a legal obligation; 
(iv) protection of vital interests of data subject; (v) pursuit of public interest; (vi) legitimate interest. Through the application of the exclusion method, it can be concluded that the most appropriate legal basis applicable to personal data processing in the framework of antiterrorist screening appears to be the legitimate interest, even if the legal basis provided in Art. 6 par. 1 (c) of the GDPR "processing is necessary for compliance with a legal obligation to which the controller is subject", would be the most legally certain. First, however, let us deal with the exclusion of some of the legal bases mentioned above.

In our opinion, it is inadmissible for the processing of personal data in the framework of anti-terrorist screening to take place with the consent of the natural person applying for employment. As in the processing of the employee's personal data, there can be doubts about the real freedom of expression, as there is a clear imbalance between the employer and the job seeker. Fear of a natural person applying for a job from failure in the selection process deprives them of this will. If the data subject does not have real or free will or cannot refuse or revoke consent without fear of adverse consequences, consent shall be deemed not to have been given. Non-freedom of consent makes it non-existent, which means that the employer processes personal data without a legal basis. It should also be borne in mind that if the processing were nevertheless carried out on the basis of the consent and the data subject refused to give the same, the employer would prevent itself from achieving the purpose pursued by such anti-terrorist screening.

The surest legal basis to apply to any processing operation is compliance with a legal obligation. In order to establish the legal basis in question for making a processing operation legal, the processing needs to satisfy the necessity of carrying out an obligation imposed by law, for which the controller is objectively held liable. The literature differs on whether this legal basis also covers the permitted possibility of processing, or only an explicit obligation to process (Nulíček, 2017, Berthoty, 2018). If this legal basis subsumes only the legal obligation of processing, it is necessary to rely on another legal basis, either on the public interest (Art. 6 par. 1 (e) of the GDPR) or on the legitimate interest (Art. 6 par. 1 (f) of the GDPR). The basis for processing personal data to fulfil a legal obligation of the controller must be laid down in the law of the European Union or in the law of the Member State applicable to the controller. It must be said here that the European Union anti-terrorism legislation ${ }^{3}$ does not have an explicit obligation on the employer to carry out such anti-terrorist screening. The Union anti-terrorist regulation implicitly infers the principle of prohibition of aiding, according to which it may be prohibited to receive,

\footnotetext{
${ }^{3}$ Council Regulation (EC) No 2580/2001 of 27 December 2001 on specific restrictive measures directed against certain persons and entities with a view to combating terrorism, Council Regulation (EC) No 881/2002 of 27 May 2002 imposing certain specific restrictive measures directed against certain persons and entities associated with the ISIL (Da'esh) and Al-Qaida organizations, Council Regulation (EU) No 36/2012 of 18 January 2012 concerning restrictive measures in view of the situation in Syria and repealing Regulation (EU) No $442 /$ 2011, Council Regulation (EU) No 267/2012 of 23 March 2012 concerning restrictive measures against Iran and repealing Regulation (EU) No 961/2010, Council Regulation (EU) 2016/1686 of 20 September 2016 imposing additional restrictive measures directed against ISIL (Da'esh) and Al-Qaeda and natural and legal persons, entities or bodies associated with them and Council Decision (CFSP) 2016/1693 of 20 September 2016 concerning restrictive measures against ISIL (Da'esh) 'esh) and Al-Qaeda and persons, groups, undertakings and entities associated with them and repealing Common Position 2002/402 / CFSP.
} 
employ or pay salaries to suspected terrorists. The so-called prohibition of aid principle has been laid down in the EU anti-terrorism regulations. According to this principle, it may be prohibited to hire, employ or pay wages to suspected terrorists (Demmel, 2015). In order for an employer to do so, it is essential to subject job seekers and employees to anti-terrorist screening. Applicability of the legal basis under Art. 6 par. 1 (c) of the GDPR is thus a matter of legal interpretation. If we lean towards the fact that this legal basis subsumes not only a legal obligation, but also the legal admissibility of personal data processing, the basis for such processing is laid down in the European Union law. However, we must draw attention to the fact that in this respect the Union law does not differentiate between individual categories of employees and does not take into account, e.g., the amount of the staff member's salary as a relevant element of any aid aimed at supporting or disseminating information about the terrorist movement. Thus, taking into account an employee whose income from the employer is objectively marginal, it is questionable whether an anti-terrorism screening can be carried out in the light of the interference with the rights of the data subject. It should be borne in mind that any processing of personal data, albeit on the legal basis of a legal obligation, must be necessary. If we conclude that the implementation of anti-terrorist screening can be applied to any job seeker without taking into account the nature of the work performed, the employee's inclusion in the employer's organizational structure and their real ability to support a terrorist movement in any way through their own salary or work, we find ourselves contradicting the GDPR, as the processing of personal data without taking these aspects into account will not be necessary.

On the contrary, if the interpretation of Art. 6 par. 1 (c) of the GDPR is restrictive, it is necessary to look for another legal basis for anti-terrorist screening. Particularly, consideration can be given to the public interest (according to Art. 6 par. 1 (e) of the GDPR), which, however, serves primarily for the processing of personal data by public authorities, or may also be used by private law entities if they are entrusted with the performance of a certain task of a public authority. Employers in the private sector may process personal data in the context of this processing operation under the legal basis pursuant to Art. 6 par. 1 (f) GDPR, i.e. "processing is necessary for the purposes of legitimate interests pursued by the controller or by a third party, except where such interests are overridden by the interests or fundamental rights and freedoms of the data subject which require protection of personal data." This is the most flexible legal basis but linked to other obligations of the employer. The controller may not process personal data under this legal basis if the interests and / or fundamental rights and freedoms of the data subjects whose personal data are to be processed outweigh the legitimate interest. It follows that, before processing personal data on that legal basis, it is necessary for the controller to assess the legitimate interest defined thereby, both in terms of its legitimacy and in terms of whether the interests of the data subject outweigh those interests. It happens in the so-called balance test and only its positive result, i.e., the conclusion that the legitimate interest pursued by the employer is indeed justified and does not outweigh the interests of the data subject, entitles the employer to use this legal basis. As part of the assessment, the employer should always answer the question before processing personal data on this legal basis whether the data 
subject can reasonably expect, at the time and in the context of the collection of personal data, that its processing can take place for that purpose. At the same time, it is necessary to assess the legitimate interest of the controller always in the light of a specific purpose of processing with regard to the specific job position and the scope of personal data that the employer is to process. If the employer hires airport staff, it is in its legitimate interest to carry out anti-terrorist screening of job seekers, because there is a legitimate and factual reason for such processing in the nature of the work. If hiring concerns supermarket staff, achieving a positive balance test result will be very difficult, if not impossible. In our view, the argument used in the balance test that the income provided for the performance of work could be used to finance terrorist activities, and therefore should not be provided, cannot stand. The use of income from any employment for funding terrorism is too hypothetical and disproportionately restricts the right of access to employment and, in general, the right to work. The fight against funding terrorism is a crucial aspect of the fight against terrorism, but it is inappropriate to conclude that anti-terrorist screening by employers is permissible for the purpose of filling any vacancy.

\section{Anti-terrorist screening in the context of Slovak national regulations}

A possibility that the legal eligibility or obligation to conduct anti-terrorist screening of a job seeker may be regulated also by national legislation needs to be accounted for as well.

In the conditions of the Slovak Republic, the legal aspects of filling vacancies are regulated by Act no. 311/2001 Statutes, the Labour Code as amended (hereinafter referred to as the "Labour Code") and Act no. 5/2004 Statutes on Employment Services, as amended (hereinafter referred to as the "Employment Services Act"). Pursuant to Art. 11 and $\S 41$ par. 5 and 6 of the Labour Code and $\S 62$ par. 3 of the Employment Services Act, the employer may request from a natural person applying for a job and subsequently collect only information about it that is related to the work to be performed (Olšovská et al., 2020). The employer may not actively obtain information that the employer may not request from a natural person, either by itself or through third parties. If non-work-related information has also been provided by the job seeker, it may not be subject to screening or any other processing. Anti-terrorist screening of job seekers is thus not a prohibited practice in the conditions of the Slovak Republic either but must have a factual connection to the work that will be performed in the vacancy to be filled.

A legal option of checking whether the job seeker has not committed the crime of terrorism in the conditions of the Slovak Republic is to request information from them on their integrity. According to the Slovak Criminal Code, the offences of terrorism are the crime of establishing, conspiring and supporting a terrorist group, the crime of terror, the crime of terrorist attack, the crime of certain forms of participation in terrorism, the crime of terrorist funding, the crime of travelling for terrorism and crime-specific motive, i.e., with the intention to commit one of the terrorist offences. Pursuant to $\S 41$ par. 6 (c) of the Labour Code, the employer may not request information on integrity from a natural person, except where work is concerned for which integrity is required by a special regulation, or if the requirement of integrity is required by the nature of the work to be 
performed by the natural person. An example of special regulations that require integrity of an applicant is Act no. 55/2017 Statutes on Civil Service as amended, Act no. 552/2003 Statutes on the Performance of Work in the Public Interest, Act no. 73/1998 Statutes on the Civil Service of Members of the Police Force, the Slovak Information Service, the Prison and Judicial Guard Corps of the Slovak Republic and the Railway Police, Act no. 35/2019 Statutes on Financial Administration as amended, Act no. 138/2019 Statutes on Pedagogical Employees and Professional Employees as amended, Act no. 473/2005 Statutes on the provision of services in the field of private security as amended (Private Security Act), etc.

As follows from the provisions of $\S 41$ par. 6 (c) of the Labour Code, the requirement of a potential employee's proof of integrity may also be set by the employer itself, due to the nature of the work performed. The employer is then obliged to determine the nature of the criminal offenses, or the merits of such, and the degree of fault (intent, negligence), the commission of which would be incompatible with the performance of work at the job to be assigned. The general requirement of a "clean" criminal record is disproportionate. The refusal of a candidate who has committed an offense unrelated to the work to be performed is a breach of their right of access to employment.

The second theoretical option of legally subjecting a job seeker to anti-terrorist screening is to establish a "clean personality profile"4 as a requirement for the performance of work in the vacancy to be filled in the employer's internal regulations. In accordance with Slovak legislation, it is possible for an employer to fill vacancies with candidates who meet the requirements set by the employer. Of course, the employer must bear the burden of proof and justify the inclusion of a certain trait, ability, personal characteristic in the requirements for the performance of work, i.e., it must be able to prove a causal link between the nature of work performed (agreed type of work, job position, conditions of filling the job position) and obtaining certain data. For certain types of work, it is thus possible to require special abilities or personality characteristics of the employee, e.g. verbal, mathematical, mechanical skills, performance, concentration, etc., but also eventual absence of contacts with defective persons, or absence of listing on the antiterrorist list as a requirement for work performance, provided that this requirement is really needed and necessary and related to the specific the type of work and the activity carried out as a part of it. With respect to the above, however, we consider that the inclusion of anti-terrorism screening among the requirements for filling a position in that context should be more burdensome for the employer in relation to objectifying the need to verify this information with the employee, as there is a significant risk of infringing the rights of data subjects, in particular the right to privacy. Also as a result of this fact, we believe that such a requirement could be demanded by employers of no less than the managers working right under the executives or of employees whose nature of work might pose a possible risk to the legitimate interests of the employer, e.g., in relation to damage to its reputation,

\footnotetext{
${ }^{4}$ This term usually conceals an investigation into the employee's various contacts with a problematic person; persons who are politically exposed, persons who are, e.g., investigated for various offenses, but also, e.g., listed on anti-terrorist lists, or checking possible manifestations of support expressed by a natural person with various terrorist groups, attacks, movements, etc.
} 
proceedings against business partners and to the establishment and acquisition of business relationships, etc. However, the inclusion of such a requirement when filling a vacancy would, in our opinion, be out of proportion for a traditional employee without contacts with the employer's business partners, in the absence of contact with representatives from other countries, etc. (Kupec, Kretter, 2013).

Given that it is possible for the employer to set requirements with respect to how the job to be assigned be performed, we believe a suitable legal basis for the processing of personal data in this case is not the employer's legal obligation, but its legitimate interest under Art. 6 par. 1 (f) of the GDPR. In a broader legal framework, proponents of the theory that the legal basis under Art. 6 par. 1 (c) of the GDPR comprises not only a legal obligation, but also a legal eligibility (explained in part 2.2 of the paper), could argue by referring to Article 11 of the Basic Principles of the Labour Code, which lists the types of information and data that an employer can process about an employee (or a job seeker). These are personal data relating to the employee's qualifications and professional experience and data which may be relevant to the work which the employee is to perform, performs or has performed. The issue of information about the candidate subject to anti-terrorist screening could fall within the scope of information that may be relevant to the work that the employee is to perform. The assessment of whether such information is of such nature is at the sole discretion of the employer (Ključnikov, Mura, Sklenár., 2019), who must also be able to bear the burden of proof that it is entitled to collect and process such data under either of the legal bases of Art. 6 par. 1 of the GDPR. Regardless of the legal basis chosen by the employer, the need to process personal data will have to be demonstrated on a causal link between work performance and the specific data that the employer has processed on the employee under the anti-terrorism screening. The scope of this data will vary depending on the work performed, as the scope of relevant information that the employer needs to collect will also be given by the complexity (difficulty) of the type of work performed, the place where the work is performed, or by possible use of devices or tools for carrying out work, etc.

\section{Resources for Anti-terrorist Screening and Legality of Their Use}

Legislation aims to limit the content of pre-employment background check but does not explicitly limit the sources from which information about the job seeker can be obtained. However, even here, these sources must be used legally. The most used source for checking whether an employee sympathizes with terrorism in any way is the Internet and especially social networks (Liolias, Řičánek, 2019).

Verifying information about potential employees from publicly available sources, typically from social networks, is currently cheap and affordable. Personnel specialists confirm that on the basis of an online (digital) trace, an individual may be invited to a job interview or even recruited, but also rejected or unnecessarily disadvantaged, although it may later turn out that the information provided has been distorted or even untrue (Bohmová, Pavlíček, 2013). User profiles on social networks provide enough personal and behavioural data that can indicate unwanted behaviour. Comments on events, published photographs, posts, group memberships, lifestyle presentations have a more transparent explanatory value for 
the HR specialist than a résumé or a cover letter. Employers even feel entitled to monitoring social networks of job seekers in order to avoid mistakes in the selection of employees (Mitran, 2010).

Checking information about a candidate on a social network is not a priori illegal, but it is a slippery slope in which the practice can become such. Statements and speeches on social network may or may not express support for terrorism. Their classification made in isolation could lead to erroneous conclusions. The words used and the context in which they are published should be taken into account. ${ }^{5}$ In order to ensure that the HR specialist does not obtain information that is unrelated to the work performed at vacancy to be filled, he should limit the sources of his search. Creating a user profile on a social network is done primarily for the purpose of spending one's free time there, and therefore, the users legitimately expect that such activity will be separated from work life and its content will not permeate it (Thomas, Rothschild, Donegan, 2015). The HR specialist should, therefore, limit his search for information on candidates for screening purposes only to such social networks and such content that is related to the public presentation of the applicant's person, or a social network profile has been created directly for the purpose of presenting work skills. (LinkedIn). We believe that even checking information on possible participation / sympathy with terrorism for the purpose of not recruiting a candidate who expresses such sentiments is not a reason to check private social accounts.

Official lists of persons drawn up for this purpose may be considered a suitable source for anti-terrorist screening in order to detect unwanted terrorist behaviour. Various measures are being taken at European Union level to combat terrorism, such as improving the exchange of information, strengthening controls at external borders, preventing online radicalization, improving firearms controls, digitizing judicial cooperation and criminalizing terrorist offenses and preventing terrorist funding. Joint efforts in the fight against terrorism, especially in the last two areas mentioned, have resulted in compilation of a terrorists list. This list of persons, groups, and entities involved in terrorist acts, subject to restrictive measures, was drafted by the European Union as early as December 2001 as its counter-terrorism response to the attacks of September 11, 2001. The list was made to implement the UN Security Council Resolution 1373 (2001) adopted pursuant to Chapter VII of the UN Charter. To this end, the Council adopted Common Position 2001/931 / CFSP (17) and Regulation No. 2580/2001 (18). This list includes persons and groups operating both inside and outside the European Union. The list is periodically reviewed, not less frequently than every 6 months. The last revision of the list dates back to 5 February 2021, covering the next six months (Point 4 COUNCIL REGULATION (EC) No 2580/2001 of 27 December 2001 on specific restrictive measures directed against certain persons and entities with a view to combating terrorism).

What should be borne in mind is that personal data are processed by searching the list and further checking the candidate's information on the Internet, i.e., this activity must be further legally assessed under the GDPR. The fact that personal data are in the public domain is irrelevant. Before adoption of the GDPR, we had a legal basis in the Slovak

\footnotetext{
5 Judgment of the European Court of Human Rights and Freedoms Demirel and Ates v. Turkey no. 11976/03 of
} 9.12.2008, § 27 . 
Republic, according to which the controller could process personal data without the consent of the data subject if personal data that had already been published in accordance with the law were processed and the controller duly marked them as originating from public domain. Personal data published in accordance with the law could be deemed personal data published by the data subjects about themselves and personal data that is legitimately publicly available to anyone (Matejka, 2013). However, it was not clear whether the information published on social networks, i.e., on a publicly available domain, acquired a public character in making the content of the information available to anyone, or maintained its personal (private) character (Žul'ová, 2016). The adoption of the GDPR has removed the controversy. The processing of publicly available information is like processing any other information. The employer must choose an appropriate legal basis for the processing of publicly available information and inform the data subject of this processing operation within the meaning of Art. 13, or 14 of the GDPR. An appropriate legal basis for processing of personal data obtained by checking a potential employee's background against publicly available sources on the Internet is a legitimate interest under Art. 6 par. 1 (f) of the GDPR.

\section{Conclusion}

In addition to standard pre-employment screening, anti-terrorist screening is becoming more common in many industries. The purpose of such screening is to prevent terrorism and maintain security. There is no reason to prevent checking the background of potential employees against terrorists lists, as long as this process is carried out in accordance with the law. However, no review can prevent what has not yet happened, and this is also a context in which anti-terrorist screening should be approached.

Counter-terrorism screening should be objectively justified by the nature of the work performed at the position to be filled. We consider it inappropriate to introduce a general system of screening in the form of anti-terrorist screening of every single job seeker when filling every single vacancy under the pretext of counter-terrorism. The aim of antiterrorist screening cannot be implementation of flat restrictions on suspects' access to employment and their prevention from earning income from employment, because the use of these resources for terrorist purposes is, in our view, too theoretical and hypothetical. Narrowing anti-terrorist screening selectively to certain types of employment (transport, energy, armaments and other regulated sectors), or rather to the nature of the work to be performed at a particular position to be filled, is closer to justified restriction of fundamental rights and freedoms of the data subject, i.e., to the principle of proportionality. The more important the employee's work is for the company, the more likely it is that anti-terrorist screening will be in order.

Anti-terrorist screening interferes with the job seeker's privacy and restricts their right to personal data protection. Thus, the legal framework for personal data protection applies. We have analyzed mainly the obligation of the employer to treat the processing operation under a suitable legal basis in this paper. We lean to the fact that the Union law does not explicitly oblige every single employer to carry out anti-terrorism screening in the hiring process. The appropriate legal basis under which this processing operation should 
be carried out is the legitimate interest of the controller under Art. 6 par. letter (b) GDPR. Processing operation under a legal basis is also required if counter-terrorism screening is carried out using publicly available sources (e.g., the list of terrorists maintained by the European Union). What definitely does not apply is that the public availability of personal data allows employers to process such personal data for the selection of a suitable candidate.

\section{Declaration of Conflicting Interests}

The authors declared no potential conflicts of interest with respect to the research, authorship, and/or publication of this article.

\section{Acknowledgements}

The scientific paper has been prepared as a part of the grant project VEGA 1/0790/20 Employee Protection in the context of Industrial Revolution 5.0 - Backgrounds, Options and Risks.

\section{References}

Berthoty, J. et al. (2018). V̌̌eobecné nariadenie o ochrane osobných údajov. Praha, C. H. Beck, 240.

Bohmová, L., Pavlíček, A. (2013). Personalistika a budoucnost sociálních sítí v ČR. Scientific Papers of the University of Pardubice. Series D, Faculty of Economics \& Administration, 20(27), 14-22.

Demmel, A. (2015). Anti-terrorist Screening Obligations Employers on the Horns of a Dilemma. Retrieved April 13, 2021, from https://www.squirepattonboggs.com/ /media/ files/insights/publications/2015/01/anti-terror-2/antiterrorscreeningsalert.pdf.

Dolobáč, M. (2017). Hranice zmluvnej slobody v pracovnom práve. Košice, Univerzita Pavla Jozefa Šafárika v Košiciach, 111.

European Union Terrorism Situation and Trend Report 2020. European Union Agency for Law Enforcement Cooperation 2020. Retrieved April 13, 2021, from https://www.europol. europa.eu/activities-services/main-reports/european-union-terrorism-situation-and-trend -report-te-sat-2020.

Guidelines for consent under the General Regulation on Personal Data Protection no. 2016/679 of 10 April 2018. Retrieved April 10, 2021, from https://www.uoou.cz/assets/ File.ashx?id_org=200144\&id_dokumenty=31896.

Hitka, M. et al. (2019). Knowledge and Human Capital as Sustainable Competitive Advantage in Human Resource Management. Sustainability, 11(18), Article Number 4985.

Ključnikov, A., Mura, L, Sklenář, D. (2019). Information security management in SME's: factors of success. Entrepreneurship and Sustainability Issues, 6(4), 2081-2094.

Kondrasuk, J. N. (2004). The Effects of 9/11 and Terrorism on Human Resource Management: Recovery, Reconsideration, and Renewal. Employee Responsibilities and Rights 
Journal, 16(1), March 2004. Retrieved April 10, 2021, from https://www.cstsonline.org/ assets/media/documents/workplacepreparedness/KondrasukJN_Effects911HumanReso. pdf.

Kupec, V., Kretter, A. (2013). Measurement of data attributes. Communication today, 4(1), 106-116.

Kupsa, J. (2008). Možnosti aktivních preventivních opatření k omezení hrozby terorismu, Blahož, J., Lidská práva a právní politika boje proti terorismu. Praha: Vysoká škola aplikovaného práva, 45-49.

Liolias, A., Řičánek, M. (2019). Pre-employment background screening. Kdy může zaměstnavatel „lustrovat“" potenciální zaměstnance? Práce a mzda, 2019, 67(7-8), 17-24.

Matejka, J. (2013). Internet jako objekt práva: hledání rovnováhy autonomie a soukromí. Praha, CZ.NIC, 100.

Mitran, A. (2010). Using social networks for staff recruiting. Romanian Journal of Journalism \& Communication (Journal of Journalism and Communication), 5(2), 59-69. Nováčková, D. et al. (2020). Financial crime in economic affairs: case study of the Slovak Republic. Juridical Tribune - Tribune Juridica, 10, 142-163.

Nulíček, M. et al. (2017). GDPR - Obecné nařízení o ochraně osobních údajů, Praktický komentář. Praha, Wolters Kluwer, 128-129.

Olšovská, A. et al. (2020). Skončenie pracovného pomeru. Bratislava, Wolters Kluwer, $2020,88$.

Thomas, S. L., Rothschild, P. C., Donegan, C. (2015). Social Networking, Management Responsibilities, and Employee Rights: The Evolving Role of Social Networking in Employment Decisions. Employ Respons Rights Journal, 27, 307-323.

Tucker, P. (2016). Refugee or Terrorist. OBM Thinks Is Software Has the Answer (Defense One, 27 January 2016). Retrieved April 10, 2021, from http://www.defenseone.com/technology/2016/01/refugee-or-terrorist-ibm-thinks-its-software-hasanswer/125484/.

Zaušková, A., Bobovnický, A., Madleňák, A. (2013). How can the state support the innovations to build sustainable competitive advantage of the country. Serbian journal of management, 8(2), 255-267.

Zaušková, A. et al. (2014). Problems of innovative thinking advocacy within the Christian doctrine. European Journal of Science and Theology, 10(3), 81-87.

Zoričáková, V. (2020). Agreement on withdrawal in labor relations and limits of labor law regulation. Central European Journal of Labour Law and Personnel Management, 3(2), 18-30.

Žulová, J. (2016). Používanie sociálnych sietí pri výbere zamestnancov (z pracovnoprávneho hladiska). Justičná revue: časopis pre právnu teóriu a prax, 68(6-7), 729-736. 


\section{Legislation}

Act. No. 311/2001 Coll. Labour Code.

Council Regulation (EC) No 2580/2001 of 27 December 2001 on specific restrictive measures directed against certain persons and entities with a view to combating terrorism.

Council Regulation (EC) No 881/2002 of 27 May 2002 imposing certain specific restrictive measures directed against certain persons and entities associated with the ISIL (Da'esh) and Al-Qaida organizations.

Council Regulation (EU) No 36/2012 of 18 January 2012 concerning restrictive measures in view of the situation in Syria and repealing Regulation (EU) No 442 / 2011.

Council Regulation (EU) No 267/2012 of 23 March 2012 concerning restrictive measures against Iran and repealing Regulation (EU) No 961/2010.

Council Regulation (EU) 2016/1686 of 20 September 2016 imposing additional restrictive measures directed against ISIL (Da'esh) and Al-Qaeda and natural and legal persons, entities or bodies associated with them.

Council Decision (CFSP) 2016/1693 of 20 September 2016 concerning restrictive measures against ISIL (Da'esh) 'esh) and Al-Qaeda and persons, groups, undertakings and entities associated with them and repealing Common Position 2002/402 / CFSP.

Judgment of the European Court of Human Rights and Freedoms Demirel and Ates v. Turkey no. 11976/03 of 9.12.2008, § 27.

Regulation of the European Parliament and of the Council of the European Union no. $2016 / 679$ on the protection of individuals with regard to the processing of personal data and on the free movement of such data, repealing Directive no. 95/46/EC. 